\title{
INVESTIGATION OF THE RELATIONSHIP BETWEEN ATTITUDE AND IMPRESSION MANAGEMENT IN UNIVERSITY STUDENTS
}

DOI: 10.17261/Pressacademia.2020.1226

JMML- V.7-ISS.2-2020(3)-p.81-90

\section{Olgun Irmak Cetin}

Trakya University, Kesan Yusuf Capraz School of Applied Sciences, Edirne, Turkey. oirmakcetin@trakya.edu.tr, ORCID:0000-0002-2534-944X

Date Received: February 26, 2020

Date Accepted: May 12, 2020

To cite this document

Cetin, O. I., (2020). Investigation of the relationship between attitude and impression management in university students. Journal of Management, Marketing and Logistics (JMML), V.7(2), p.81-90.

Permanent link to this document: http://doi.org/10.17261/Pressacademia.2020.1226

Copyright: Published by PressAcademia and limited licensed re-use rights only.

\section{ABSTRACT}

Purpose- The aim of this study is to reveal the relationship between attitude and impression management based on their thoughts on impression management while revealing the relationship between attitude and impression management among university students.

Methodology- For this purpose, a survey was conducted with students within the body of Trakya University, Keşan Yusuf School of Applied Sciences, and the results were evaluated.

Findings- According to the results obtained, between the "Positive Approach" sub-dimension towards attitude and "Self Promotion" for the impression management sub-dimension, it is positive, moderate and significant; It is understood that there is a positive, strong and meaningful relationship between the "Negative Approach" sub-dimension towards attitude and "Intimidation" towards the impression management subdimension.

Conclusion- Accordingly, the students who show "Positive Approach" adopt the impression management of "Self Promotion"; It is revealed that the students who have a "Negative Approach" have adopted the impression management of " Intimidation".

Keywords: Impression management, social perception, attitude, positive approach, self promotion.

JEL Codes: D23, M12, M14

\section{INTRODUCTION}

One of the important universal tendencies towards human being is to try to have an idea about someone else with limited knowledge. The individual wants to make an impression about a person he or she sees, even for a short time. The first impression established affects the knowledge and expectations of the individual about that person. The observable traits of an encountered person give a clue to the individual to make inferences about him. Therefore, the first impression constitutes the first step in the social interaction of the individual.

Attitude is defined as the situation assessment of the individual regarding any event or object. Since attitude is a function of the individual's beliefs and values, it is effective in the emergence of thoughts, feelings, and behaviors. If the individual's attitude is based on the past, then it is a core structure and its change is often difficult. If the attitude is formed based on environmental influences, then it may be way more easier to change.

As a result of human being as a social entity and interacting mutually with other people, they gain some impressions towards the other side or give various impressions about themselves. One of the general characteristics of human being is to try to make an impression about other individuals based on limited information and clues. The individual makes inferences about the people he encounters by making use of his observable traits such as appearance, behavior, gesture, and facial expressions. 


\section{LITERATURE REVIEW}

In this part of the study, theoretical information about attitude and impression management, which forms the theoretical basis of the research, will be included.

\subsection{Attitude}

Attitude is one of the most obvious and indispensable concepts in social psychology (Ajzen and Fishbein, 1977). The concept of attitude can be defined as the reactive tendency shown by the individual as a result of the situations developing around him (Gün and Gökçe, 2017). The individual directs his attitudes and behaviors with his emotional integrity (Acaray and Günsel, 2017). Because attitude is an important tester of behavior (Erkuş, Sanlı, Bağlı, and Güven, 2000). Likewise, Fazio and Zanna (1981) defined attitude as a response to environmental stimuli that occurs in the mental world of the individual and turns into behavior. There are studies in the sense that attitude can be measured by an individual's cognitive level and intention (Kaiser, Wölfing, and Fuhrer, 1999). The individual's response to the same event and at different times is interpreted as the attitude level is stable (Schwarz, 2007). In another definition, the attitude is expressed as a tendency to respond generally positively or negatively according to the object of the attitude (Robinson, Stimpson, Huefner, and Hunt, 1991). The broadest definition that can be made can be given as the general assessment of the individual about the person, subject or object (Petty and Brinol, 2010).

Kan and Akbaş (2005), who quoted it from Ülgen (1996), emphasized that it is a phenomenon gained through learning for attitude, directing the behavior of the individual and causing bias in the decision-making process. If the individual develops a positive attitude towards an object, situation and person, he will tend to approach these, show affinity, support or help him (Uzun and Sağlam, 2006). Similarly, the magnitude, severity, and direction of the individual's response to their environment are shaped by the individual's attitude (Çapri and Çelikkaleli, 2008).

There are studies conducted that attitudes differ from opinions, values and beliefs (Üstüner, 2006). Accordingly, the most important point that separates the views from the attitudes is that the views can be generalized and the measurement technique is different. Opinions are individual reactions to events and situations that have taken place. Attitude, on the other hand, contains more general meanings than the opinion. It is the directing individual response to broad events and groups of people. According to Tezbaşaran (1997), people are aware of their views, but they may not be fully aware of their attitudes. There are also differences between value and attitude. The value is wider in scope than attitude. Value evokes accuracy, desirability, and ethical codes. It symbolizes beliefs about the preferability of opposite behaviors, individually or socially. The differences between belief and attitude arise from constant emotions created by perceptions and definitions. Faith often forms the basis of personal principles. When the individual wants to express his belief and opinion, he expresses this with his own attitudes.

\section{Impression Management}

Impression management is a broader and more comprehensive term than manifesting itself (Leary and Kowalski, 1990). It helps the individual in reaching his goals and developing his objectives (Bolino, 1999). Likewise, it has been determined by researches that impression management is affected by personal goals (Hooghiemstra, 2000). Thanks to the individual impression management, he will be able to create the image he wants in the minds of others (Harris, Kacmar, Zivnuska, and Shaw, 2007). Impression management is a concept attributed to the individual in the process of social perception and interaction. Social perception is the way the individual perceives actors other than his own and the perceptual organization he establishes about them (Armağan, 2012). The social interaction process is the interaction, attitude and behavior that an individual develops with others as a result of being a social asset. It would not be wrong to say that impression management is essentially a concept related to personal well-being and interpersonal relations (Uziel, 2010). However, O'sullivan (2000) evaluated impression management as the primary function of relational interactions. Impression management is also an element that affects the mobility of the individual (McDonnell and King, 2013). With the impression management, the individual aims to: maximize the reward-cost ratio by obtaining social and material results; to increase self-esteem and develop the desired identity (Doğan and Kılıç, 2010).

In the field of work, the employee can increase his admirability thanks to impression management (Harris et al., 2007). Impression management is a process in which individuals try to influence the perception of others about their images (Singh, Kumra, and Vinnicombe, 2002).

Similarly, Alga and Özdemir (2018), who quoted from Goffman (1959), stated that Impression management is often an element of social interaction. According to Alga and Özdemir (2018), impression management is "acting as an actor who plays the role of a person to realize her own interests, displaying certain behaviors and making statements to influence others." A different definition was emphasized by Aygün and Toptan (2015) as "the process of control and orientation that includes various behaviors 
aimed at influencing the perception and thoughts of other individuals in order to create the goals and identity that individuals desire". In addition to this, it is defined that individuals have "efforts to obtain a positive image through positive thoughts to be created on the target audience" (Gürbüz, 2018).

A conclusion that can be drawn from the definitions on impression management; is that impression management is a function of control, orientation, monitoring or impact concepts.

Formation of impression management behaviors can take place in two different types (Doğan and Kılıç, 2010). Firstly, it is that the behaviors towards impression management are rooted. The individual performs deep-rooted behavior as a result of a habit and does not reflect on it. The other is that the individual behaves situationally and reacts accordingly to events.

The concept of impression management was first mentioned theoretically and scientifically in "The Presentation of Self in Everyday Life" by Erwin Goffman, published in 1959. According to Goffman, daily life is a theater stage, as emphasized in the work of Shakespeare. Accordingly, the individual is an actor that performs in front of the others. It became a subject for social psychology in the studies by Snyder, Arkin, Shepherd, Ralston and Elsass. Based on this, impression management has been evaluated as perception manipulation until 1980 's. After that, it has become a subject to be discussed in terms of organizational behavior. In the 1990s, it has come to the fore that impression management has many dimensions and it should be handled individually, organizationally and theoretically. In this period, impression management tactics were evaluated.

The individual can develop different tactics for impression management. Serin, Balkan, and Soran (2014), who quoted these tactics from Bolino (1999), defined:

\section{Figure 1: Impression Management Tactics}

\begin{tabular}{|c|c|}
\hline \multirow[t]{3}{*}{ Ingratiation } & There are many good things about being loved by others socially. \\
\hline & This strategy can be defined as flattery and favor to look cute. \\
\hline & $\begin{array}{l}\text { This tactic is one of the offensive impression management tactics, and the shared goal is to look } \\
\text { attractive to other employees. }\end{array}$ \\
\hline \multirow[t]{2}{*}{ Self Promotion } & $\begin{array}{l}\text { This tactic is an effort to ensure that people are viewed as talented and competent in terms of their } \\
\text { ability and special abilities. }\end{array}$ \\
\hline & $\begin{array}{l}\text { Thus, it involves efforts to demonstrate that it is the person who deserves them, both in gaining respect } \\
\text { of the other party and in gaining interests such as "promotion" or "wage increase". }\end{array}$ \\
\hline \multirow[t]{2}{*}{ Exemplification } & This tactic is that individuals work above and beyond their duties to look like they're dedicated to the job. \\
\hline & $\begin{array}{l}\text { The person who adopts this tactic desires to create the impression of an employee who comes to work } \\
\text { early in the working environment, brings work constantly to her home, does not get permission unless } \\
\text { compulsory and is identified with her job. }\end{array}$ \\
\hline \multirow[t]{2}{*}{ Intimidation } & Individuals look intimidating or threatening and want others to see them as dangerous. \\
\hline & The person using the intimidation tactic tries to gain social power by being seen as a dangerous person. \\
\hline \multirow[t]{2}{*}{ Supplication } & It can be defined as showing destitute to appear in need of others. \\
\hline & $\begin{array}{l}\text { This tactic can also be used to get rid of some heavy responsibilities and to serve as a justification for } \\
\text { possible failures. }\end{array}$ \\
\hline
\end{tabular}

When the figure is examined, it is seen that impression management includes tactics of ingratiation, self promotion, exemplification, intimidation, and ingratiation. 
The number of publications investigating impression management and attitude behavior is limited in both domestic and foreign literature. All studies are given below. Firstly, domestic publications were examined and then foreign publications were evaluated.

The study titled "The Examination of the Impression and Attitude towards Doctors in the Context of the Discourse Created for Doctors in the Written Media" by Söylet and Çakar Mengü (2011) is the first and only source in Turkish regarding attitude and impression. The study has two stages. In the first stage, a questionnaire was applied to 300 people selected by the random and current patient position at Istanbul University Faculty of Medicine and Cerrahpaşa Medical Faculty in order to determine the way patients perceive their relations with doctors and the factors that cause this perception. In the second stage, using discourse analysis, the discourse designed for the personal and professional qualities of the doctors, the features and functions of the hospitals, as well as the doctor - patient relations were discussed in the print media. As a result, doctors need to tell patients and the society in general, using the media and other channels, the nature of their work, its difficulty, its stages, their education and the processes they have undergone. Negative perceptions and prejudices towards the image of the doctor in the society can be turned into a positive situation with various communication strategies.

The study titled "Body image perception, eating attitude and influence of media among undergraduate students of medical college in Delhi: a cross sectional study" was conducted by Sharma, Singh, Tiwari, and Chauhan (2019). The aim of the study is to determine body image perception, abnormal eating attitudes and the role of the media among undergraduate students of a medical school in Delhi, India. For this purpose, a survey was conducted with 370 students in India. Looking at the results obtained, it is understood that educational and preventive efforts should be made at institutional levels to promote a healthy body image and eating behavior.

\section{DATA AND METHODOLOGY}

In this part of the study, target population of the study, sample and method will be discussed to examine the relationship between attitude and impression management variables.

The target population of the study is composed of university students, and the sample of the study is students who study at Keşan Yusuf School of Applied Sciences. Students study in Banking and Insurance (BI), Computer Technologies and Information Systems (CTIS), Customs Business (CB), Business Information Management (BIM) and International Trade (IT). Questionnaires were delivered to students online. 168 questionnaires were completed completely and without errors and accepted as valid. Participation numbers of the departments and classes in the survey are given in the table below.

Table 1: Department and Class Distribution of Students

\begin{tabular}{|c|c|c|c|c|c|}
\hline \multirow{2}{*}{ Department } & \multicolumn{5}{|c|}{ Grade } \\
\hline & 1 & 2 & 3 & 4 & TOTAL \\
\hline Banking and Insurance & 3 & 8 & 4 & 7 & 22 \\
\hline Computer Technologies and Information Systems & 2 & 9 & 7 & 5 & 23 \\
\hline Customs Business & 4 & 33 & 29 & 25 & 91 \\
\hline Business Information Management & 0 & 3 & 7 & 4 & 14 \\
\hline International Trade & 2 & 4 & 5 & 7 & 18 \\
\hline TOTAL & 11 & 57 & 52 & 48 & 168 \\
\hline
\end{tabular}

As can be seen from the table, participation in the survey was mostly from the Customs Business Department. The reason for this is that the author works in this section. Other departments participated in the survey as much as possible.

\subsection{Scales of the Study}

In the analysis section of the study, questionnaires were used as the main basis. The variables in the survey were measured using the 5-point Likert Scale (1: Strongly Agree, 5: Strongly Disagree). Surveys consist of three parts. In the first part, there are demographic and socio-economic questions. In this section, 4 questions were asked as age, gender, department and class. In the second part, participants were asked about attitude and in the last part, impression management questions were asked.

The attitude scale was compiled from the scale developed by Suna, Atik, Karaman, and Çok (2013) to analyze students' attitude development behavior. The scale developed by Suna et al. Consists of 52 items and 2 sub-dimensions. 302 questionnaires were evaluated for the development of the Attitude Scale. While the questionnaires consisted of 71 questions, the findings were 
reduced to 52 statements based on the findings. The questionnaire questions were collected in two sub-dimensions, namely

Positive Approach and Negative Approach.

The impression scale was developed by Basim, Tatar, and Sahin (2006). 518 men participated in the study. The scale developed by Basım et al., Bolino and Turnley (1999) was used. The scale contains 22 questions in its original form.

\subsection{Analysis Method}

SPSS program was used in the analysis part of the research. Firstly, demographic and socio-economic data were analyzed. Then, validity and reliability analyzes were performed for the variables and finally, regression analysis and the relationships between variables were discussed. Demographic and socio-economic data of the students participating in the survey are given in the table below.

Table 2: Demographic and Socio-Economic Factors

\begin{tabular}{|c|c|c|c|c|c|c|c|}
\hline $\begin{array}{l}\text { Demographic } \\
\text { Factor }\end{array}$ & Sub Group & $\mathbf{N}$ & \% Frequency & $\begin{array}{l}\text { Demographic } \\
\text { Factor }\end{array}$ & Sub Group & $\mathbf{N}$ & \% Frequency \\
\hline \multirow{3}{*}{ Age } & -17 & 45 & $27 \%$ & \multirow{5}{*}{ Department } & $\mathrm{BI}$ & 22 & $13 \%$ \\
\hline & $18-20$ & 55 & $33 \%$ & & CTIS & 23 & $14 \%$ \\
\hline & 20 and more & 68 & $40 \%$ & & $\mathrm{CB}$ & 91 & $54 \%$ \\
\hline \multirow{2}{*}{ Gender } & Woman & 81 & $48 \%$ & & BIM & 14 & $8 \%$ \\
\hline & Man & 87 & $52 \%$ & & IT & 18 & $11 \%$ \\
\hline \multirow{4}{*}{ Grade } & 1 & 11 & $7 \%$ & & & & \\
\hline & 2 & 57 & $34 \%$ & & & & \\
\hline & 3 & 52 & $31 \%$ & & & & \\
\hline & 4 & 48 & $29 \%$ & & & & \\
\hline
\end{tabular}

It can be seen from the table that students are generally 20 years and older (40\%). The number of male students (87) is slightly higher than the number of female students (81). The lowest proportion of students among the grades shows the students who are first graders (7\%). There is a slightly balanced distribution between Grades 2, 3 and 4. In terms of distribution among departments, the CB division is by far ahead (54\%).

The data were evaluated by factor analysis for validity test. Factor analysis results are given in the table below.

Table 3: Factor and Reliability Analysis

\begin{tabular}{|c|c|c|c|c|c|}
\hline & Factor & Expression & $\begin{array}{c}\text { Explained } \\
\text { Variance (\%) }\end{array}$ & $\begin{array}{l}\text { KMO } \\
\text { Value }\end{array}$ & $\begin{array}{c}\text { Cronbach } \\
\text { Alfa }\end{array}$ \\
\hline \multirow{2}{*}{ 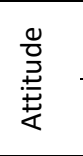 } & Positive Approach & $\begin{array}{l}\text { T5, T15, T16, T19, T22, T30, T31, } \\
\text { T32, T34, T37, T45, T57 }\end{array}$ & 39,43 & \multirow{2}{*}{0,919} & 0,956 \\
\hline & Negative Approach & $\begin{array}{l}\text { T13, T21, T28, T29, T36, T40, T46, } \\
\text { T47, T49, T50, T55 }\end{array}$ & 28,87 & & 0,947 \\
\hline \multirow{2}{*}{ 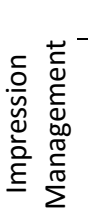 } & Self Promotion & $\mathrm{Y} 2, \mathrm{Y3}, \mathrm{Y} 6, \mathrm{Y} 7, \mathrm{Y} 12, \mathrm{Y} 13, \mathrm{Y} 16, \mathrm{Y} 17$ & 35,54 & \multirow[b]{2}{*}{0,964} & 0,949 \\
\hline & Intimidation & Y1, Y4, Y9, Y11, Y14, Y19, Y21 & 43,21 & & 0,928 \\
\hline
\end{tabular}

According to the table, the KMO value of the Attitude variable is 0.919 ; It is seen that the KMO value of the Impression Management variable is obtained as 0.964 . Therefore, variables are suitable for factor analysis in terms of KMO value (Özdemir, 2008).

As a result of factor analysis, the Attitude variable is divided into 2 sub-dimensions. The dimensions were named as Positive Approach (PA) and Negative Approach (NA) as in the original. The Positive Approach sub-dimension explains $39.43 \%$ of the total variance of the Attitude variable and the Negative Approach sub-dimension explains the $28.87 \%$ of the total variance of the 
Attitude variable. The 2 sub-dimensions explain $68.3 \%$ of the total variance. The Impression Management variable is collected in 2 sub-dimensions, unlike the original. While the original scale was collected in 5 sub-dimensions, this study was divided into 2 subdimensions. The sub-dimensions were named as "Self Promotion (SP)" and "Intimidation (I)". 29 expressions for the attitude variable and 7 expressions for Impression Management were excluded from the data set because they received a factor load value close to each other or the factor load was below 0.5 (Altunışık, Coşkun, Bayraktaroğlu, and Yıldırım, 2010).

Cronbach Alpha coefficient was interpreted for the reliability of the study (Kalaycı et al., 2005). As can be seen from Table 3, the Cronbach Alpha coefficient of the Positive Approach, Negative Approach, Self Promotion and Intimidation was found above 0,900. Thus, the reliability of the scales is ensured.

\subsection{Research Hypotheses}

As a result of conceptual information and literature review, the hypotheses of the study were established as follows.

H1: Attitude in university students has a positive and significant effect on impression management.

H1a: Positive Approach attitude in university students has positive and significant effect on Self Promotion.

H1b: Positive Approach attitude in university students has positive and significant effect on Intimidation.

H1c: Negative Approach attitude among university students has a positive and significant effect on the impression management of Self Promotion.

H1d: The Negative Approach attitude of university students has a positive and significant effect on the impression management of Intimidation.

The model of the research was formed as given below by considering the hypotheses established for the study.

Figure 2: Research Model

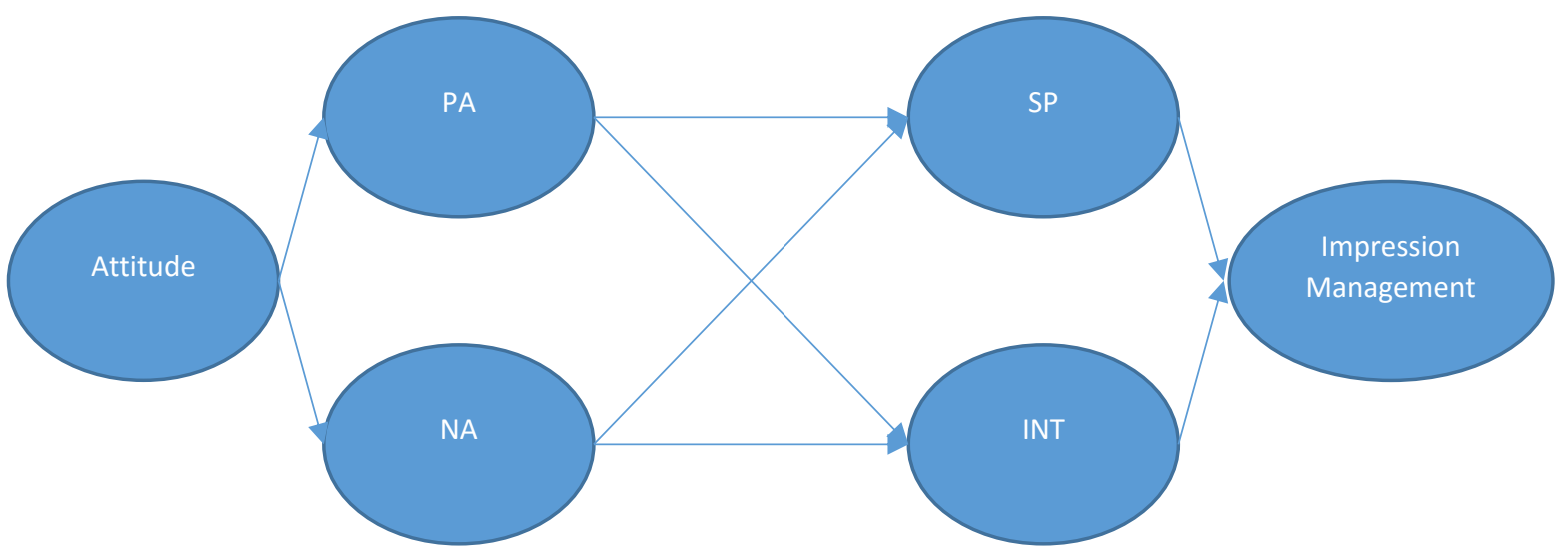

As can be seen from the figure, the Positive Approach and Negative Approach sub-dimensions of the Attitude variable affect the sub-dimensions of Impression Management, Self Promotion and Intimidation. This effect has been considered positively and significantly.

\section{FINDINGS}

SPSS program was used to test the relationships between variables. For this purpose, relations were evaluated between the Attitude behavior sub-dimensions, which is the independent variable, and the Impression Management sub-dimensions, which are the dependent variable, by using Regression Analysis.

First of all, the relationship between the Positive Approach and the Self Promotion was analyzed (Table 4). 
Table 4: PA-SP Relation

\begin{tabular}{|c|c|c|c|c|c|c|}
\hline \multicolumn{7}{|c|}{ Coefficients $^{a}$} \\
\hline \multirow{2}{*}{\multicolumn{2}{|c|}{ Model }} & \multicolumn{2}{|c|}{ Unstandardized Coefficient } & \multirow{2}{*}{$\begin{array}{c}\text { Standardized Coefficient } \\
\text { Beta }\end{array}$} & \multirow{2}{*}{$\mathbf{t}$} & \multirow{2}{*}{ Sig. } \\
\hline & & B & Std. Error & & & \\
\hline \multirow[t]{2}{*}{1} & Constant & 5,117 & 3,066 & & 1,669 & ,095 \\
\hline & SOP & 1,173 & , 086 & ,426 & 13,700 & ,000 \\
\hline
\end{tabular}

According to the table, $\mathrm{H} 1 \mathrm{a}$ hypothesis was accepted because the regression analysis between PA and SP variables is less than $0.05(p=0,000)$.

Secondly, the relationship between the Positive Approach and the Intimidation was analyzed (Table 5).

Table 5: PA-I Relation

\begin{tabular}{|c|c|c|c|c|c|c|}
\hline \multicolumn{7}{|c|}{ Coefficients $^{a}$} \\
\hline \multirow{2}{*}{\multicolumn{2}{|c|}{ Model }} & \multicolumn{2}{|c|}{ Unstandardized Coefficient } & \multirow{2}{*}{$\begin{array}{c}\text { Standardized Coefficient } \\
\text { Beta }\end{array}$} & \multirow{2}{*}{$\mathbf{t}$} & \multirow{2}{*}{ Sig. } \\
\hline & & B & Std. Error & & & \\
\hline \multirow[t]{2}{*}{1} & Constant & 10,613 & ,505 & & 21,007 & 000 \\
\hline & SOP & 282 & 021 & 424 & 13,595 & 602 \\
\hline
\end{tabular}

a. Dependent Variable: PA

According to the table, $\mathrm{H} 1 \mathrm{~b}$ hypothesis was rejected because the regression analysis between $\mathrm{PA}$ and I variables was higher than $p$ value $(p=0.602)$.

Thirdly, the relationship between Negative Approach and the Self Promotion was analyzed (Table 6).

Table 6 :NA- SP Relation

\begin{tabular}{|c|c|c|c|c|c|c|}
\hline \multicolumn{7}{|c|}{ Coefficients $^{a}$} \\
\hline \multicolumn{2}{|c|}{ Model } & \multicolumn{2}{|c|}{ Unstandardized Coefficient } & \multirow{2}{*}{$\begin{array}{c}\text { Standardized Coefficient } \\
\text { Beta }\end{array}$} & \multirow{2}{*}{$\mathbf{t}$} & \multirow{2}{*}{ Sig. } \\
\hline & & B & Std. Error & & & \\
\hline \multirow[t]{2}{*}{1} & Constant & $-16,804$ & 1,383 & & 12,148 & ,000 \\
\hline & SOP & ,002 & ,038 & ,002 & 054 & 957 \\
\hline
\end{tabular}

a. Dependent Variable: NA

According to the table, $\mathrm{H} 1 \mathrm{c}$ hypothesis was rejected because the regression analysis between NA and SP variables was higher than $p$ value $(p=0.957)$

Finally, the relationship between the Negative Approach and the Intimidation was analyzed (Table 7).

\section{Table 7: NA- INT Relation}

\begin{tabular}{l|l|c|c|c|c|c}
\hline \multicolumn{2}{l}{ Coefficients $^{2}$} \\
\multicolumn{2}{l}{ Model } & Unstandardized Coefficient & Standardized Coefficient & \multirow{2}{*}{ t } & \multirow{2}{*}{ Sig. } \\
\cline { 3 - 8 } \multicolumn{2}{l|}{} & B & Std. Error & Beta & 3,199 &, 001 \\
\hline \multirow{2}{*}{1} & Constant & 10,229 & 3,197 & & 11,498 &, 000 \\
\cline { 2 - 7 } & SOP &, 927 &, 081 &, 368 & \\
\hline
\end{tabular}

a. Dependent Variable: NA

According to the table, $\mathrm{H} 1$ a hypothesis was accepted because the regression analysis between NA and I variables is less than 0.05 $(p=0,000)$.

After all the regression analysis, the general condition of the research hypotheses resulted as follows. 
Table 8: Hypotheses Results

\begin{tabular}{lc}
\hline Hypotheses & Result \\
\hline H1: Attitude in university students has a positive and significant effect on impression management. & $\begin{array}{c}\text { Partially } \\
\text { Accepted }\end{array}$ \\
\hline H1a: Positive Approach attitude in university students has positive and significant effect on Self Promotion. & Accepted \\
\hline H1b: Positive Approach attitude in university students has positive and significant effect on Intimidation. & Rejected \\
\hline H1c: Negative Approach attitude among university students has a positive and significant effect on the & Rejected \\
impression management of Self Promotion. & Accepted \\
\hline H1d: The Negative Approach attitude of university students has a positive and significant effect on the & \\
\hline impression management of Intimidation. &
\end{tabular}

While $\mathrm{H} 1 \mathrm{a}$ and $\mathrm{H} 1 \mathrm{~d}$ were accepted from the hypotheses of the study, $\mathrm{H} 1 \mathrm{~b}$ and $\mathrm{H} 1 \mathrm{c}$ were rejected. In this case, the $\mathrm{H} 1$ hypothesis is partially accepted.

With the acceptance of the $\mathrm{H} 1 \mathrm{a}$ hypothesis, it is understood that university students who adopt a positive approach attitude behavior tend towards the Impression Management by Self Promotion.

With the rejection of the $\mathrm{H} 1 \mathrm{~b}$ hypothesis, it is understood that university students who adopt a positive approach attitude behavior do not have any interest in the impression management of Intimidation.

It is understood that university students who adopt negative approach and attitude behavior with the rejection of H1c hypothesis do not want to tend towards impression management by Self Promotion.

With the acceptance of the H1d hypothesis, it is understood that university students who adopt negative approach attitude behavior tend towards Impression Management to Intimidation.

\section{CONCLUSION}

The aim of this study is to reveal the relationship between attitude and impression management based on the thoughts of impression students about impression management while trying to create attitudes of university students. Since attitude is a function of the beliefs and values of the individual, it is effective in the emergence of thoughts, feelings and behaviors. If the individual's attitude is based on the past, it is a core structure and its change is often difficult. If the attitude is based on environmental influences, it may be easier to change. As a result of being a social entity and interacting with other people, it gains some impressions towards the other side or gives various impressions about the other side. One of the general characteristics of man is to try to make an impression about other individuals based on limited information and clues.

The analysis part of the research was carried out using the survey method. The target population of the study is composed of students studying in university while students studying in Keşan Yusuf Applied Sciences School. Students study in Banking and Insurance (BI), Computer Technologies and Information Systems (CTIS), Customs Business (CB), Business Information Management (BIM) and International Trade (IT). Surveys consist of three parts. In the first part, there are demographic and socioeconomic questions. In this section, 4 questions were asked as age, gender, department and grade. In the second part, attitude questions were asked to the participants and in the last part, impression management questions were asked. The Attitude scale developed by Suna et al. Consists of 52 items and 2 sub-dimensions. Impression Management scale developed by Basım, Tatar and Şahin consists of 22 expressions and 2 dimensions unlike the original. Factor analysis and reliability tests were applied to the data set. As a result of factor analysis, the Attitude variable is divided into 2 sub-dimensions. The dimensions were named as Positive Approach (OLY) and Negative Approach (OSY) as in the original. The Impression Management variable is collected in 2 sub-dimensions, unlike the original. While the original scale was collected in 5 sub-dimensions, it was divided into 2 subdimensions in this study. The sub-dimensions were named as "Self Promotion (SP)" and "Intimidation (I)".

Regression analysis was conducted to investigate the hypotheses of the study. While $\mathrm{H} 1 \mathrm{a}$ and $\mathrm{H} 1 \mathrm{~d}$ were accepted from the hypotheses, $\mathrm{H} 1 \mathrm{~b}$ and $\mathrm{H} 1 \mathrm{c}$ hypotheses were rejected. Therefore, the $\mathrm{H} 1$ hypothesis has been partially accepted. H1a hypothesis was established as "Positive Approach attitude in university students has positive and significant effect on Self Promotion". Students who want to create an attitude by adopting a positive approach with the acceptance of the hypothesis, think that they can make themselves loved by bringing their qualities to the fore. In fact, university students tend to draw a positive image while 
introducing themselves to their new environment in university life, which coincides with post adolescence. It also expresses its unique qualities in order to increase the likelihood of acceptance and adoption by the environment while developing a positive attitude towards them. In this way, he / she will be able to make friends with others with the same qualities or be amazed by his surroundings and join a group of friends. But for all this, they must first show a positive attitude.

The other accepted $\mathrm{H} 1 \mathrm{~d}$ hypothesis was that "The Negative Approach attitude of university students has a positive and significant effect on the impression management of Intimidation". The main factor in accepting this hypothesis is that the student has somehow adopted a negative approach and chose to communicate with her environment in a fearful, insecure, problematic and uncanny communication. The student who chooses to exhibit such an attitude will try to explain himself by forcing his environment in order to stay as a social group member. The environment will or will continue to notice the student. In this way, he will be able to stay social.

$\mathrm{H} 1 \mathrm{~b}$ and $\mathrm{H} 1 \mathrm{c}$ hypotheses were rejected. The basis of this is that the relationship between "Intimidation Impression Management with the Positive Approach and the Self Promotion Impression Management with the Negative Approach" were perceived as opposite concepts by the participants.

The study was conducted only with university students in a limited area. The fact that the research was carried out with the survey method restricts the results. This work, which will guide the future studies, has a qualification of a milestone. The results can be generalized by making continuous improvements on this basis. For later studies, samples with larger participation can be used. In addition, a qualitative research method, whose reliability is considered stronger than the survey method, can be preferred.

\section{REFERENCES}

Acaray, A., and Günsel, A. (2017). Investigation of the Relationship Between Five Factor Personality Traits, Impression Management Tactics and Subjective Well-Being: A Study on Public Employees. International Journal of Economic and Administrative Studies (19), 527. doi: 10.18092 / ulikidince. 323571

Ajzen, I., and Fishbein, M. (1977). Attitude-behavior Relations: A Theoretical Analysis and Review of Empirical Research. Psychological bulletin, 84(5), 888.

Alga, E., and Özdemir, M. (2018). Relationship between Political Skill and Impression Management in Private Sector Organizations. 16 (31), 309329.

Altunışık, R., Coşkun, R., Bayraktaroğlu, S., and Yıldııım, E. (2010). Research Methods in Social Sciences: SPSS Applied: Sakarya publishing.

Armağan, A. (2012). Media and Impression Management: Istanbul University.

Aygün, D., and Toptan, M. (2015). A Research on Determining the Impression Management Tactics Used by Professionals of Accounting. Gümüşhane University Electronic Journal of the Institute of Social Science, 6 (12), 268-291.

Basim, H. N., Tatar, I., and Sahin, N. H. (2006). Self Perception in Impression Management, Locus of Control, Level of Achieving Professional Goals and Stress: A Public Sector Case. Turkish Journal of Psychology, 21 (58), 1.

Bolino, M. C. (1999). Citizenship and Impression Management: Good Soldiers or Good Actors? Academy of Management Review, 24(1), 82-98.

Çapri, B., and Çelikkaleli, Ö. (2008). Investigation of Teacher Candidates' Attitudes Towards Teaching and Professional Competence Beliefs According to Gender Programs and Faculties. Inonu University Journal of Education Faculty, 9 (15), 33-53.

Doğan, S., and Kılıç, S. (2010). A Conceptual Review on “Impression Management Behavior” in Organizations: Atatürk University.

Erkuş, A., Sanlı, N., Bağ, M. T., and Güven, K. (2000). Development of Attitude Scale Regarding Teaching. Education and Science, 25 (116).

Fazio, R. H., and Zanna, M. P. (1981). Direct Experience and Attitude-behavior Consistency. In Advances in Experimental Social Psychology (Vol. 14, pp. 161-202): Elsevier.

Gün, M. S., and Gökçe, Ş. (2017). A Study on Attitudes and Learning Perceptions of Secondary School Students towards the Interactive Board. Mersin University Faculty of Education Journal (2), 497. doi: 10.17860 / mersinefd.336738

Gürbüz, S. (2018). Corporate Social Responsibility Activities in Creating a Corporate Image: Using Impression Management Tactics on Youtube Videos: Necmettin Erbakan University Faculty of Fine Arts.

Harris, K. J., Kacmar, K. M., Zivnuska, S., and Shaw, J. D. (2007). The Impact of Political Skill on Impression Management Effectiveness. Journal of Applied Psychology, 92 (1), 278. 
Hooghiemstra, R. (2000). Corporate Communication and Impression Management - new Perspectives Why Companies Engage in Corporate Social Reporting. Journal of Business Ethics, 27 (1-2), 55-68.

Kaiser, F. G., Wölfing, S., and Fuhrer, U. (1999). Environmental Attitude and Ecological Behaviour. Journal of environmental psychology, 19(1), 119.

Kalaycı, Ş., Albayrak, A., Eroğlu, A., Küçüksille, E., Ak, B., Karaltı, M., Öztürk, E. (2005). SPSS Applied Multivariate Statistical Techniques: Asil Yayın Dağıtım Ltd. Sti.

Kan, A., and Akbaş, A. (2005). Development Study of High School Students' Attitude Scale towards Chemistry Course. Mersin University Faculty of Education Journal, 1 (2).

Leary, M. R., and Kowalski, R. M. (1990). Impression Management: A Literature Review and Two-component Model. Psychological bulletin, 107(1), 34.

McDonnell, M.-H., and King, B. (2013). Keeping up Appearances: Reputational Threat and Impression Management after Social Movement Boycotts. Administrative Science Quarterly, 58(3), 387-419.

O'sullivan, B. (2000). What You Don't Know Won't Hurt Me: Impression Management Functions of Communication Channels in Relationships. Human Communication Research, 26(3), 403-431.

Özdemir, A. (2008). Advanced Research Methods and Applications in Management Science. Beta Publications, Istanbul.

Petty, R. E., and Brinol, P. (2010). Attitude Change. Advanced social psychology: The state of the science, 217-259.

Robinson, P. B., Stimpson, D. V., Huefner, J. C., and Hunt, H. K. (1991). An Attitude Approach to the Prediction of Entrepreneurship. Entrepreneurship theory and practice, 15(4), 13-32

Schwarz, N. (2007). Attitude Construction: Evaluation in Context. Social cognition, 25(5), 638-656.

Serin, A. E., Balkan, M. O., and Soran, S. (2014). The Effect of Conflict Management Strategies on Impression Management Tactics: A Research on University Students. 13 (50), 23-37.

Sharma, M., Singh, S. K., Tiwari, P., and Chauhan, N. (2019). Body Image Perception, Eating Attitude and Influence of Media among Undergraduate Students of Medical College in Delhi: A Cross Sectional Study. International Journal of Research in Medical Sciences, 7(12), 4627.

Singh, V., Kumra, S., and Vinnicombe, S. (2002). Gender and Impression Management: Playing the Promotion Game. Journal of Business Ethics, $37(1), 77-89$.

Söylet, Y., and Çakar Mengü, S. (2011). Impression and Attitude Formation towards Doctors; Investigation of the Discourse Created for Doctors in the Written Press. Istanbul University Faculty of Communication Journal (40), 101-122.

Suna, E. H., Atik, Z. E., Karaman, N. G., and Çok, F. (2013). Development of Attitude Scale for Young People. Education and Science, 38 (170).

Uziel, L. (2010). Rethinking Social Desirability Scales: From Impression Management to Interpersonally Oriented Self-control. Perspectives on Psychological Science, 5(3), 243-262.

Uzun, N., and Sağlam, N. (2006). Environmental Attitude Scale Development and Validity for Secondary School Students. Hacettepe University Faculty of Education Journal, 30 (30), 240-250.

Üstüner, M. (2006). Validity and Reliability Study of the Attitude Scale Towards Teaching Profession. Educational Administration: Theory and Practice, 45 (45), 109-127 